\title{
Feeding daidzein to late pregnant sows influences the estrogen receptor beta and type 1 insulin-like growth factor receptor mRNA expression in newborn piglets
}

\author{
M Q Ren ${ }^{1,2}$, G Kuhn ${ }^{1}$, J Wegner ${ }^{1}$, G Nürnberg ${ }^{1}$, J Chen $^{2}$ \\ and $\mathrm{K}$ Ender $^{1}$ \\ ${ }^{1}$ Research Institute for the Biology of Farm Animals, D-18196 Dummerstorf, Germany \\ ${ }^{2}$ Laboratory of Animal Physiology and Biochemistry, Nanjing Agricultural University, 210095 Nanjing, China \\ (Requests for offprints should be addressed to G Kuhn, Research Institute for the Biology of Farm Animals, Wihelm-Stahl-Allee 2, D-18196 Dummerstorf, \\ Germany; Email: kuhn@fbn-dummerstorf.de)
}

\begin{abstract}
The present study was undertaken to determine the tissue-specific expression of estrogen receptor beta $(\mathrm{ER} \beta)$, and the effects of a daidzein supplement to the diet of pregnant sows on the expression of $\operatorname{ER} \beta$, and type 1 insulin-like growth factor receptor (IGF-1R) genes in newborn piglets by using semi-quantitative RT-PCR. Eight sows received a dietary supplement of daidzein at a dosage of $8 \mathrm{mg}$ per $\mathrm{kg}$ feed from day 85 of gestation, and six sows were used as controls. After parturition, 2 male neonatal piglets were selected from each litter for sampling. ER $\beta$ mRNA was detected in intestine, lung, thymus, kidney, pituitary and hypothalamus tissues, but not in heart, adrenal, skeletal muscle, liver or placental tissues. Daidzein treatment significantly increased the
\end{abstract}

birth weight of male piglets and markedly reduced the level of ER $\beta$ mRNA in the hypothalamus, but not in the pituitary. An up-regulation of IGF-1R gene transcription was observed in skeletal muscles of newborn piglets. In addition, the IGF-1R mRNA was found to be most abundant in pituitary and hypothalamus, followed by skeletal muscle, thymus, and liver tissues in decreasing order. Our results demonstrate that (1) ER $\beta$ is expressed in a tissue-specific manner in newborn piglets, (2) daidzein down-regulates ER $\beta$ gene expression in the hypothalamus, possibly indicating central effects of daidzein, and (3) daidzein influences fetal growth associated with higher IGF-IR gene expression in skeletal muscle.

Journal of Endocrinology (2001) 170, 129-135

\section{Introduction}

Previous studies suggest that plant-derived phytoestrogens, especially isoflavones, are potentially therapeutic compounds for a range of estrogen-dependent diseases, such as breast cancer, menopausal symptoms, cardiovascular disease and osteoporosis (Anderson 1999, Adlercreutz et al. 2000). Isoflavones are structurally similar to mammalian endogenous estrogens (Setchell \& Cassidy 1999), and thus may act as estrogen agonists or antagonists (Setchell et al. 1998). Recent studies suggest that isoflavones act mainly through binding to estrogen receptor beta $(E R \beta)$ (Kuiper et al. 1998b, Casanova et al. 1999, Makela et al. 1999). $\operatorname{ER} \beta$ is the second subtype estrogen receptor expressed not only in reproductive organs, but also in hypothalamus, pituitary gland, lung, and other tissues in rats and humans (Kuiper et al. 1996, Enmark \& Gustafsson 1999). ER $\beta$ and ER $\alpha$ have high homology in the DNA binding domain (>95\% amino-acid identity), but the homology in the ligand binding domain is relatively low, about $55 \%$ (Gustafsson 1999). These structural differences may contribute to the different characteristics in ligand binding affinities, as well as in biological functions (Kuiper et al. 1997). It was suggested that ER $\beta$ plays important roles in brain function (Gustafsson 1999) mediating estrogen in brain development during embryogenesis (Toran-Allerand 1999). However, whether ER $\beta$ is expressed in porcine brain or other tissues is still unclear.

Daidzein, an aglycone, is an isoflavone present in large quantities in soybeans and other legumes. Recently, Liu et al. (1999) demonstrated that feeding pregnant sows with a daidzein-supplemented diet improved pre- and postnatal growth in newborn male piglets. However, the mechanisms mediating the effects of daidzein on animal growth are still unclear. Daidzein is a lipophilic substance with a molecular mass of $254 \mathrm{Da}$, thus it is able to pass through the placental barrier (Adlercreutz et al. 1999). It was demonstrated that children in Asia are born with similar plasma levels of phytoestrogens as those of their mothers, indicating a free transfer of these compounds to the fetus. It is well known that insulin-like growth factor-I (IGF-I) and -II (IGF-II) play important roles in fetal growth, and 
they both exhibit growth promoting effects via the type 1 IGF receptor (IGF-1R) (Anthony et al. 1995, Gluckman 1997). Evidence exists that estrogen regulates expression of the IGF system in vitro and in vivo. In rhesus monkey uteri and human breast tissues, the IGF-I and IGF-1R mRNA levels have been shown to be up-regulated by estradiol (Adesanya et al. 1996, Clarke et al. 1997). It is therefore hypothesized that one of the mechanisms of the daidzein prenatal growth promoting effects might be by regulating the IGF-1R and ER $\beta$ at the level of gene transcription. In order to test our hypothesis, we used RT-PCR to investigate the distribution of $\operatorname{ER} \beta$ in pig nonreproductive organs, and examined the effects of daidzein on the mRNA levels of the ER $\beta$ and IGF-1R gene in different tissues of newborn piglets.

\section{Materials and Methods}

\section{Animals and feeding}

All animals were cared for according to guidelines set by the Animal Protection Committee from the Ministry for Agriculture and Nature Protection, Schwerin, Germany. Sixteen multiparity sows (German Landrace, Pig Breeding Association North/Eastern, Germany) were mated to one German Landrace boar. Sow pregnancy was confirmed at day 28 of gestation by ultrasound. Sows had live weights of $180 \pm 7 \mathrm{~kg}$, backfat depths of $19 \pm 2 \mathrm{~mm}$ (Piglog 105, SFK Technology A/S, Herlev, Denmark) and parities of $3 \cdot 0 \pm 0 \cdot 3$. Sows were divided into experimental $(n=8)$ and control $(n=8)$ groups with balanced weight, backfat depth and parity. However, during the experiment two control sows were excluded due to skeletal system illness and premature farrowing respectively. The sows were housed individually at the pig experimental station of the Research Institute, under controlled environmental conditions $\left(19^{\circ} \mathrm{C}, 60-80 \%\right.$ relative humidity). All sows were fed twice daily with the same commercial pregnancy diet (Denkavit, Trede \& Pein GmbH \& Co. KG, Itzehohe, Germany) containing $11.8 \mathrm{MJ}$ metabolizable energy per $\mathrm{kg}$ dry matter and $14.0 \%$ crude protein. All animals had free access to water. Throughout pregnancy, sows were fed manually corresponding to the following schedule: a daily feed ration of $2.6 \mathrm{~kg}$ at the beginning of the pregnancy was increased gradually to $5 \mathrm{~kg}$ at the end of the pregnancy. This schedule guaranteed an enhanced nutritional supply to the sows during pregnancy. From day 85 of gestation until parturition the ration of the experimental sows was supplemented with $8 \mathrm{mg}$ daidzein per $\mathrm{kg}$ feed. Live weights, backfat depths, and sow parities were not significantly different between the two groups at day 85 of gestation. To induce farrowing, on day 114 of pregnancy all sows were injected intramuscularly with $1 \mathrm{ml}$ of a synthetic prostaglandin analog (cloprostenol, $75 \mathrm{mg} / \mathrm{ml}$ : AniMedica West, Chemische Produkte GmbH, Senden, Germany).

\section{Sample collection}

After sow parturition, body weight and sex of newborn piglets were recorded. Two male piglets with body weights close to the mean were selected from each litter. Within $6 \mathrm{~h}$ after birth, daidzein piglets $(n=16)$ and control piglets $(n=12)$, were anesthetized with $1 \mathrm{ml}$ of a mixture (v:v=1:1) of ursotamin and combelen and were then killed. Brains were removed immediately from the skull and the pituitary glands were collected. Boundaries used for dissecting the hypothalamus were as follows: rostral edge of the optic chiasm, immediate rostral to the mamillary body, width of the optic chiasm. The thymus, liver, longissimus dorsi muscle, heart (ventricle), small intestine (ileum), lung, adrenal gland and kidney (cortex) were also collected. Additionally, after parturition fresh placental tissue (endometrium) was collected. All samples were immediately frozen in liquid nitrogen and stored at $-70{ }^{\circ} \mathrm{C}$ until RNA isolation.

\section{RNA extraction, $c D N A$ synthesis, and polymerase chain reaction}

Total RNAs were isolated from tissue samples using the RNeasy mini kit (QIAGEN, Atsworth, CA, USA) according to the manufacturer's instructions. RNA yields and purities were assessed by absorbance at 260 and $280 \mathrm{~nm}$ in a RNA/DNA Calculator (Amersham Pharmacia Biotech Europe, Freiburg, Germany). Ratios of absorption $(260 / 280 \mathrm{~nm})$ of all preparations were between $1 \cdot 8$ and $2 \cdot 0$. Aliquots of RNA samples were subjected to electrophoresis to verify their integrity.

The cDNA was synthesized using $1 \cdot 0 \mu \mathrm{g}$ total RNA from each sample. RNA samples were denatured at $65^{\circ} \mathrm{C}$ for $15 \mathrm{~min}$ and placed on ice for $5 \mathrm{~min}$ before reverse transcription (RT). The final reaction volume, $25 \mu \mathrm{l}$, contained $1 \times$ reaction buffer, $5 \mathrm{mM} \mathrm{MgCl}_{2}, 1 \mathrm{mM}$ dNTPs, $3 \cdot 2 \mu \mathrm{g}$ random primer $\mathrm{p}(\mathrm{dN})_{6}, 50$ units RNase inhibitor, $0.01 \mathrm{mg} / \mathrm{ml}$ gelatin and 20 units AMV reverse transcriptase (1st strand cDNA synthesis kit, Boehringer Mannheim Corp., Indianapolis, IN, USA). The reaction was performed at $25^{\circ} \mathrm{C}$ for $10 \mathrm{~min}, 42^{\circ} \mathrm{C}$ for $60 \mathrm{~min}$, $99^{\circ} \mathrm{C}$ for $5 \mathrm{~min}$ for enzyme heat inactivation, and $4{ }^{\circ} \mathrm{C}$ for 5 min. RT products were either stored at $-20^{\circ} \mathrm{C}$ or used directly for PCR. To eliminate residual genomic DNA from the RNA sample, prior to the RT reaction, 1 unit DNaseI (Roche Diagnostics, Mannheim, Germany) was added and incubated at $37^{\circ} \mathrm{C}$ for $30 \mathrm{~min}$ followed by heat-inactivation of the enzyme at $75{ }^{\circ} \mathrm{C}$ for $5 \mathrm{~min}$ (Huang et al. 1996). Genomic DNA amplification contamination was checked periodically by control experiments in which reverse transcriptase (positive control) or RNA (negative control) were omitted during the RT step.

PCR was performed in a $50 \mu$ reaction volume containing $2 \cdot 0 \mu \mathrm{l}$ tissue-specific cDNA (equivalent to $80 \mathrm{ng}$ of starting RNA), $1.5 \mathrm{mM} \mathrm{MgCl}_{2}, 2$ units Taq DNA 
polymerase (Boehringer Mannheim $\mathrm{GmbH}$, Mannheim, Germany), $0.2 \mathrm{mM}$ dNTPs and $0.4 \mu \mathrm{M}$ of each primer. For amplification of the target genes, the following primer pairs were used: ER $\beta$ (GeneBank accession no. AF164957) forward 5'-TCTCCTGTCTCCTACAACT GCA and reverse 5'-GGCATCCCTCTTTGAACTT GGA, for amplification of a 396-bp fragment of pig ER $\beta$ cDNA; IGF-1R (GeneBank accession no. AB003362) forward 5'-CCCAAAGTCTGTGAGGAAGAGA and reverse 5'-TTAGTCCCTGTCACTTCCTC-CA, for amplification of a 422-bp fragment of pig IGF-1R cDNA. Additional reactions were run using primers for $\beta$-actin (GeneBank accession no. U07786) forward 5'-GGAGA TCGT GCGGGACATCAAG and reverse 5'-GGCGTA GAGGTCCTTCCTGATG, to serve as a control. These primers amplify a 269-bp fragment of pig $\beta$-actin cDNA. To obtain optimal conditions for amplification, in the exponential phase of PCR the cycle numbers were tested first for each target gene. Plotting PCR signal intensity (as expressed by net intensity) against the number of amplification cycles revealed a strong linear relationship between cycles 32 and 40 for ER $\beta$ (correlation coefficient $\left.r^{2}=0.996\right)$, and between cycles 24 and $32\left(r^{2}=0.983\right)$ for IGF-1R.

QuantumRNA 18S primer and competimer (Ambion, Inc. Austin, TX, USA) were used as internal controls of amplification. This primer pair (catalog no. 1716) amplifies a 488-bp fragment. The ratio of $18 \mathrm{~S}$ primer to competimer was 1:9 for ER $\beta$ and IGF-1R genes. Amplifications were performed in a Biometra Personal Cycler (Biomedizinische Analytik GmbH, Göttingen, Germany). For $\mathrm{ER} \beta$ the following cycle parameters were used: $120 \mathrm{~s}$ at $94{ }^{\circ} \mathrm{C}, 36$ cycles at $94{ }^{\circ} \mathrm{C}$ for $40 \mathrm{~s}, 60^{\circ} \mathrm{C}$ for $50 \mathrm{~s}, 72^{\circ} \mathrm{C}$ for $40 \mathrm{~s}$. For IGF-1R, we used 28 cycles at $94^{\circ} \mathrm{C}$ for $40 \mathrm{~s}$, $57^{\circ} \mathrm{C}$ for $45 \mathrm{~s}, 72^{\circ} \mathrm{C}$ for $45 \mathrm{~s}$. Each reaction was followed by $5 \mathrm{~min}$ at $72{ }^{\circ} \mathrm{C}$ and continuous hold at $4{ }^{\circ} \mathrm{C}$. After amplification, $10 \mu \mathrm{l}$ of each PCR product were analyzed by agarose gel electrophoresis $(2 \%)$.

\section{Quantitation of PCR products (image analysis)}

Gels were stained with ethidium bromide and photographed with a 3-CCD color camera using an image analysis system (Quantimet 570, Leica Cambridge Ltd, Cambridge, UK). Net intensities of individual bands (same area) were measured using Kodak Digital Science 1D software (Eastman Kodak Company, Rochester, NY, USA). Ratios of net intensity of target genes to that of the internal control bands (QuantumRNA 18S) were calculated before statistical analysis. To minimize the between-assay error, samples from two groups were always processed in parallel.

\section{Statistical analysis}

All values are reported as means \pm S.E.M. Data were analyzed by ANOVA (STATISTICA program V5·0,
Table 1 Pregnancy characteristics in the daidzein group (sows suppplemented with $8 \mathrm{mg}$ daidzein per $\mathrm{kg}$ feed) compared with the control group. Values are means \pm S.E.M.

\begin{tabular}{|c|c|c|c|}
\hline & Daidzein & Control & Significance \\
\hline \multicolumn{4}{|l|}{ Parameter } \\
\hline No. of sows & 8 & 6 & \\
\hline No. of piglets/litter & $13 \cdot 3 \pm 1 \cdot 0$ & $14 \cdot 7 \pm 1 \cdot 2$ & ns \\
\hline \multicolumn{4}{|l|}{ Birth weight $(\mathrm{kg})$} \\
\hline Male & $1 \cdot 31 \pm 0 \cdot 04$ & $1 \cdot 17 \pm 0 \cdot 04$ & $P<0.05$ \\
\hline Female & $1 \cdot 25 \pm 0 \cdot 03$ & $1 \cdot 17 \pm 0 \cdot 04$ & \\
\hline Survival (\%) & $98 \cdot 35 \pm 1 \cdot 75$ & $90 \cdot 43 \pm 1 \cdot 87$ & $P<0.05$ \\
\hline
\end{tabular}

ns, not significant.

StatSoft Inc., Tulsa, OK, USA) using a mixed model. For piglet performance data, treatment and piglet gender were employed as fixed factors, sow as a random factor and litter size as a covariant factor. Tissue mRNA levels were processed with the same model including tissue as a fixed factor, without including gender. Means were compared by Tukey HSD (honest significant difference) unequal number multiple comparison test. Student's $t$-test was used in the analysis of unpaired data.

\section{Results}

Body weights of newborn piglets and percentage of survival

The birth weight of male piglets in the daidzein-treated group was significantly higher $(P<0 \cdot 05)$ than that of the control group. However, female piglets were not found to have different birth weights. Sows fed with daidzein had a higher $(P<0 \cdot 05)$ percentage of survival than that of control sows (Table 1).

\section{Tissue distribution of ER $\beta m R N A$ in newborn piglets}

Using RT-PCR, ER $\beta$ mRNA was detected in intestine, lung, thymus, kidney, pituitary and hypothalamus, but not in heart, adrenal gland, skeletal muscle, liver or placental tissues. The highest expression of ER $\beta$ mRNA was found in the hypothalamus. This was followed closely by the pituitary and the kidney which expressed a moderate level of ER $\beta$ mRNA, while expression in intestine, lung and thymus tissues was quite low (Fig. 1).

\section{Effects of daidzein on ER $\beta m R N A$ levels in hypothalamus} and pituitary tissues

Relative mRNA levels of ER $\beta$ in the hypothalamus and the pituitary were measured by semi-quantitative RT-PCR. Compared with the control group, ER $\beta$ mRNA levels in the hypothalamus were markedly reduced in the daidzein group $(P<0 \cdot 05)$ (Fig. 2A,C). 

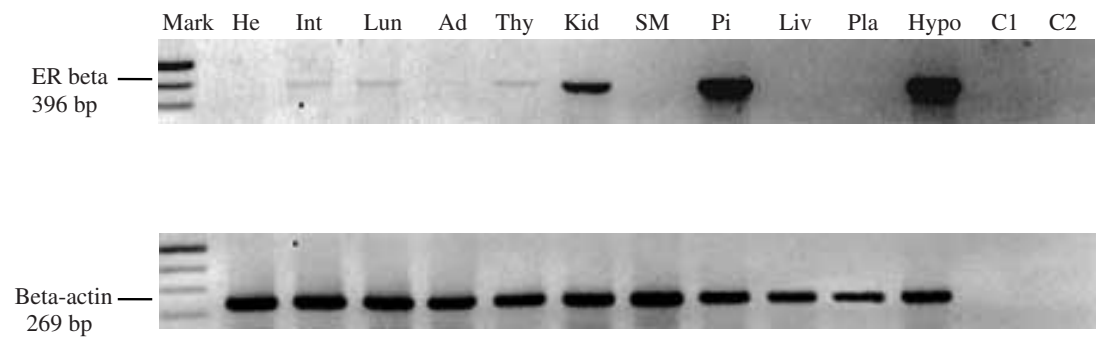

Figure 1 Tissue distribution of ER $\beta$ gene expression in newborn piglets. Qualitative RT-PCR was performed on $2 \mu \mathrm{g}$ total RNA from newborn piglets using primers specific for pig ER $\beta$ transcripts (GeneBank accession no. AF164957), cDNA (3 $\mu$ l) for PCR amplification, cycle number 38; other parameters are the same as those of quantitative RT-PCR presented in the Materials and Methods section. Gel electrophoresis (2\%) shows RT-PCR products of the ER $\beta$ gene in intestine (Int), lung (Lun), thymus (Thy), kidney (Kid), pituitary ( $\mathrm{Pi}$ ) and hypothalamus (Hypo). However, no RT-PCR products are present in heart ( $\mathrm{He})$, adrenal gland (Ad), skeletal muscle (SM), liver (Liv), or placental (Pla) tissues. RT-PCR for $\beta$-actin was carried out as a positive control. C1 and C2 are negative controls where reverse transcriptase and RNA respectively were omitted during the RT step.

However, in pituitary tissue no differences were found between the two groups (Fig. 2B,C). In the daidzein group, expression of ER $\beta$ mRNA was lower $(P<0 \cdot 05)$ in the hypothalamus compared with the pituitary, whereas in the control group there was no noticeable difference between these two tissues.

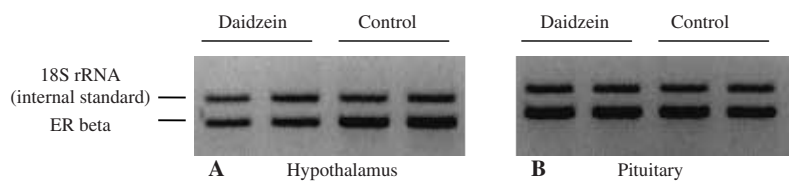

C

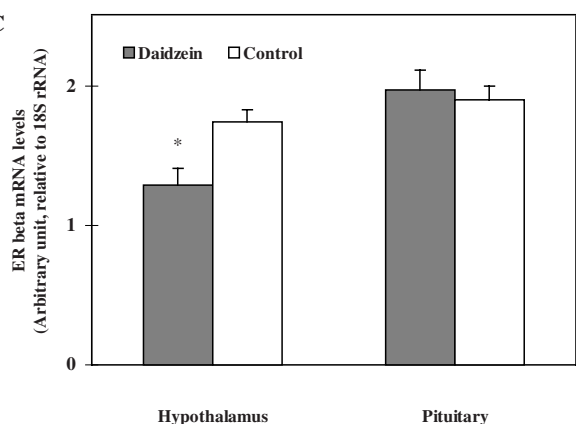

Figure 2 Effects of daidzein feeding in late pregnant sows on ER $\beta$ gene expression of newborn piglets. Gel electrophoresis (2\%) shows RT-PCR products of ER $\beta$ from (A) hypothalamus and (B) pituitary tissues in two groups compared with $18 \mathrm{~S}$ ribosomal RNA (internal standard). (C) Relative levels of ER $\beta$ mRNA - e.g. RT-PCR products of ER $\beta$ in hypothalamus and pituitary tissues in the daidzein $(n=16)$ and control $(n=12)$ groups were normalized with the internal standard; every sample was measured in duplicate. Expression of ER $\beta$ was significantly $(P<0.05)$ reduced in the hypothalamus in the daidzein group compared with that of the control group, but was unchanged in the pituitary. Levels are given as means \pm S.E.M. ${ }^{*} P<0 \cdot 05$ vs levels from corresponding control (ANOVA followed by Tukey HSD unequal number multiple comparison test).

\section{IGF-1R $m R N A$ levels in newborn piglet tissues}

The expression of IGF-1R in different tissues of newborn piglets in the daidzein and control groups is presented in Fig. 3. Compared with the control group, relative muscle IGF-1R mRNA levels in the daidzein-fed group were significantly higher $(P<0 \cdot 05)$. IGF-1R mRNA levels in thymus and liver tissues increased in the daidzein group $(P=0.08$ and $P=0.09$ respectively), while no significant changes were detected in the hypothalamus or the pituitary. In addition, relative mRNA levels of IGF-1R gene were highest in the hypothalamus and pituitary, moderate in skeletal muscle and thymus, and were lowest in the liver.

\section{Discussion}

Since the discovery of the ER $\beta$ subtype by Kuiper et al. (1996), many studies have shown that this receptor is expressed in multiple rat, mouse, and human tissues, in addition to the reproductive system tissues (Kuiper et al. 1998a, Casanova et al. 1999). These discoveries have improved our knowledge of the mechanism of action of estrogen and its analogs. However, information about ER $\beta$ distribution in pigs is limited. Here, we have shown that there is ER $\beta$ mRNA expression in hypothalamus and pituitary tissues of newborn piglets. High amounts of ER $\beta$ transcripts were previously found in the pituitary of the pre-pubertal rat (Mitchner et al. 1998, Wilson et al. 1998), human (Shupnik et al. 1998), and rhesus monkey (Pau et al. 1998), whereas levels in mouse pituitary appeared to be low or nearly undetectable (Couse et al. 1997). It has been reported that the expression of ER $\beta$ is high in rat and human fetal hearts (Saunders 1998). In the present experiment we failed to detect ER $\beta$ mRNA in the heart of newborn piglets. Levels of ER $\beta$ expression in fetal human 


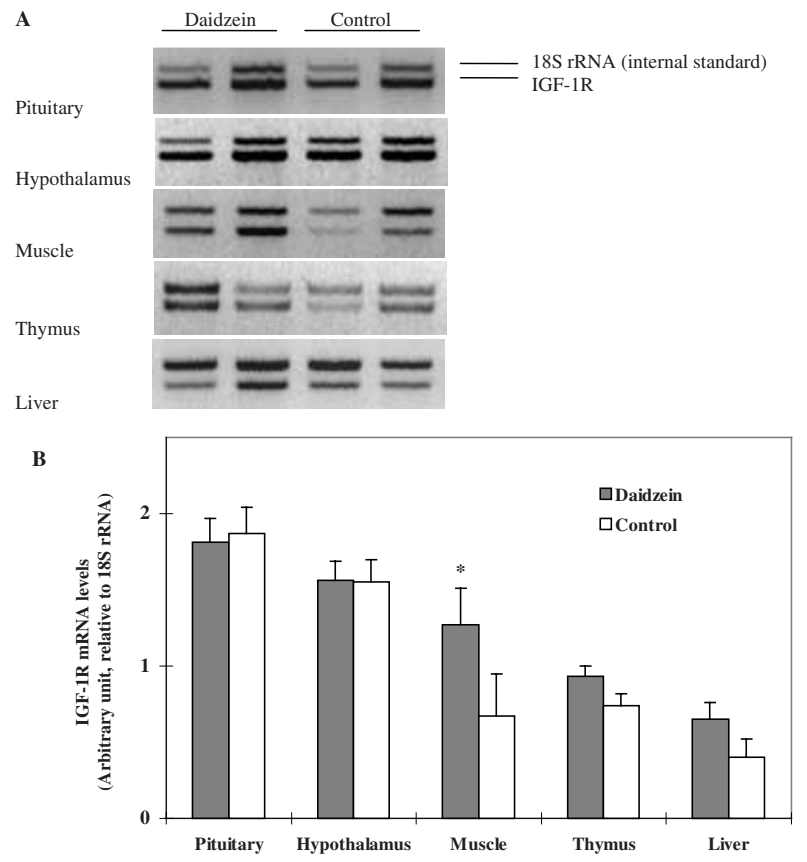

Figure 3 Expression of IGF-1R in different tissues of newborn piglets in the daidzein and control groups. (A) Gel electrophoresis (2\%) shows RT-PCR products of IGF-1R from different tissues in two groups compared with $18 \mathrm{~S}$ ribosomal RNA (internal standard). (B) Semi-quantitative RT-PCR of IGF-1R mRNA (duplicate representative tests) - e.g. RT-PCR products of IGF-1R of each tissue in the daidzein $(n=16)$ and control $(n=12)$ groups were normalized with internal standard. Compared with those of the control group, relative IGF-1R mRNA levels in muscle were significantly enhanced $(P<0 \cdot 05)$, and IGF-1R mRNA levels of thymus and liver were inclined to increase in the daidzein group $(P<0 \cdot 1)$. No significant changes were detected in hypothalamus or pituitary tissues.

However, expression of IGF-1R gene was found to be highest in the hypothalamus and the pituitary, modest in muscle and thymus, and lowest in the liver. Levels are reported as means \pm S.E.M. ${ }^{*} P<0.05$ vs levels from corresponding control (ANOVA followed by Tukey HSD unequal number multiple comparison test).

and rat kidneys are low or undetectable (Brandenberger et al. 1997), but we detected moderate expression in newborn piglets. ER $\beta$ signals detected in the thymus and the intestinal tract of newborn piglets were very weak; however very high expression in humans and rats has been reported (Enmark \& Gustafsson 1999). High expression has been reported in the adrenal gland of human fetuses (Brandenberger et al. 1997). In our experiment, ER $\beta$ expression in the adrenal gland was not detected in newborn piglets which is in accord with results reported from prepubertal rats (Saunders 1998). No ER $\beta$ transcripts have been found in rat or human livers (Enmark \& Gustafsson 1999). Using RT-PCR, mRNAs of ER $\beta$ in skeletal muscle, liver and placental tissue of newborn piglets were also undetectable in our experiment. Expression of the ER $\beta$ gene thus appears to be drastically different among tissues and species.
Since the hypothalamus and pituitary expressed the most abundant ER $\beta$ mRNA, we chose these two types of tissue to try and elucidate further the effects of daidzein. The results of ER $\beta$ expression in the pituitary are similar to those reported by Mitchner et al. (1998) who demonstrated that estradiol did not alter the expression of ER $\alpha$ or ER $\beta$ in rat pituitaries. However, observations by Schreihofer et al. (2000) showed that ER $\beta$ mRNA levels fell $40 \%$ on the morning of proestrus and were suppressed by estradiol or dihydrotestosterone in ovariectomized female rat pituitaries. Schreihofer et al. (2000) also reported that progesterone or progesterone plus estradiol suppressed ER $\beta$ gene expression in rodent pituitary cell lines, yet the relative levels of ER $\beta$ mRNA in testes were increased after neonatal estrogen exposure (Tena-Sempere et al. 2000). Very recently, it was found that daidzein is capable of significantly down-regulating the androgen receptor and the ER $\alpha$ mRNA expression in rat uteri (Diel et al. 2000). Data accumulated so far suggest that the effects of estrogen or its agonists on ER gene expression are tissue-specific and vary in different species. Our results demonstrate that daidzein regulates ER $\beta$ expression in a tissue-specific manner at the transcription level. The expression of ER $\beta$ in the hypothalamus was significantly down-regulated by daidzein, suggesting a direct effect of daidzein acting as an estrogen agonist on the hypothalamus-pituitary neuroendocrine functions. Dietary genistein exerted estrogenic effects upon the hypothalamic-pituitary axis in rats, increased plasma prolactin (Santell et al. 1997), and enhanced growth hormone $(\mathrm{GH})$ release in rat anterior pituitary cells (Ogiwara et al. 1997). The serum levels of luteinizing hormone and prolactin in the pig were increased by supplemented daidzein feeding (Liu et al.1999).

Both in vitro and in vivo experiments have shown that exogenous estrogens enhance cell (Lee et al. 1999) and tissue (Klotz et al. 2000) proliferation and growth. The growth promoting effect of exogenous estrogen in domestic animal production has been known for a long time (Lamming 1957). The exact mechanism of this phenomenon is still unclear, but it is partially correlated with estrogen modulating growth-axis functions. Research indicates that exogenous estrogen augments serum concentrations of GH in cattle (Breier et al. 1988) and sheep (Phelps et al. 1988), and of IGF-I in cattle (Coxam et al. 1990). Zeranol, a synthetic estrogen used for stimulating growth in domestic animals, was found to increase serum concentrations of IGF-I in lambs (Hufstedler et al. 1996), and GH gene expression in pituitaries of wethers (Thomas et al. 2000). Our results, together with previous findings (Liu et al. 1999) suggest that daidzein improves male fetal growth, while no significant influence was observed in female newborn piglets. Wang et al. (1995) found that daidzein injected subcutaneously into rats increased male rat growth and was attended by higher growth hormone levels; the results in the female rats were the opposite. 
Daidzein has demostrated both agonistic and antagonistic effects. At low plasma estrogen levels, daidzein acted agonistically, while at high plasma levels it acted antagonistically (Setchell \& Cassidy 1999). Recently, it was demonstrated that estrogen is important for male animal growth (Vanderschueren et al. 1997, Sharpe 1998, Toran-Allerand et al. 1999). Results from our study and others (Wang et al. 1995, Liu et al. 1999) show that daidzein may act agonistically in males by promoting fetal growth, while potentially acting antagonistically in female piglets.

It is clear that both IGF-I and IGF-II play major roles in controlling the growth of skeletal muscles (Florini et al. 1996). In vitro (Ewton et al. 1987) and in vivo (Yu \& Czech 1984) studies demonstrated that IGF-1R mediates several anabolic actions of IGF-I and IGF-II, including stimulation of amino acid uptake, proliferation and differentiation in skeletal muscle. Results indicate a possible association between higher birth weight and daidzein-enhanced IGF-1R gene expression in skeletal muscle. However, we did not detect $\operatorname{ER} \beta$ in newborn piglet muscle. $\operatorname{ER} \alpha$ but not ER $\beta$ has been proven to mediate effects of estrogen in the skeleton of male mice during growth and maturation (Vidal et al. 2000). Therefore, it is reasonable to assume that daidzein-influenced muscle IGF-1R gene expression might be effected via ER $\alpha$.

In rat hypothalamus, Pons et al. (1991) found that IGF-1R was highest during the fetal phase and steadily decreased thereafter to low levels in adult rats. Our results support this observation. Results suggest an important role for IGF-I in the growth and differentiation of the brain in the fetus (D'Ercole et al. 1996), and are consistent with phenomena observed in postnatal brain growth retardation. In breast and uterus tissues, IGF-I and IGF-1R levels were increased by estradiol or combinations of estradiol and progesterone (Clarke et al. 1997). In rat hypothalamic cell cultures, Pons \& Torres-Aleman (1993) found that the addition of $17 \beta$-estradiol elicited a significant increase in type-1 IGF receptor protein levels in neurons. In the present study, IGF-1R mRNA levels in the hypothalamus and pituitary were unchanged after daidzein feeding. However, the IGF-1R mRNA levels in skeletal muscle were up-regulated, and the IGF-1R mRNA levels were increased in liver and thymus tissues. These results suggest that estrogen and/or other agonists regulate IGF-1R levels also in a tissue-specific manner and indicate that the IGF system may be a critical regulator of estrogen-mediated growth (Klotz et al. 2000).

To our knowledge, this is the first study to investigate the distribution of $\operatorname{ER} \beta$ in pigs, and is also the first study to provide in vivo evidence that daidzein inhibits $\operatorname{ER} \beta$ gene expression in the hypothalamus of pigs. Knowledge about the expression levels of ER $\beta$ in different tissues may be valuable for re-evaluating mechanisms of action for estrogen agonists and antagonists in a tissue-specific manner. Our results suggest that one way daidzein may influence fetal growth is via up-regulation of IGF-1R expression in skeletal muscle. The down-regulation of $\operatorname{ER} \beta$ gene expression in the hypothalamus indicates the possible central effects of daidzein on the neuroendocrine system.

\section{Acknowledgements}

This study was supported by The Federal Ministry for Nutrition, Agriculture, and Forestry of Germany and The Agricultural Ministry of China (grant no. 27/1999-2000). The authors would like to thank Ms M Günther and Ms $\mathrm{U}$ Bretschneider for technical assistance. Our thanks are extended to Dr R Q Zhao (Prince Henry's Institute of Medical Research, Clayton, Australia) for useful discussion and to Mr P W Huff for proofreading the paper.

\section{References}

Adesanya OO, Zhou J \& Bondy CA 1996 Sex steroid regulation of insulin-like growth factor system gene expression and proliferation in primate myometrium. Journal of Clinical Endocrinology and Metabolism 81 1967-1974.

Adlercreutz H, Yamada T, Wahala K \& Watanabe S 1999 Maternal and neonatal phytoestrogens in Japanese women during birth. American Journal of Obstetrics and Gynecology 180 737-743.

Adlercreutz H, Mazur W, Bartels P, Elomaa V, Watanabe S, Wahala K, Landstrom M, Lundin E, Bergh A, Damber JE, Aman P, Widmark A, Johansson A, Zhang JX \& Hallmans G 2000 Phytoestrogens and prostate disease. Journal of Nutrition 130 658S-659S

Anderson JJB 1999 Effects of phyto-oestrogens on tissues. Nutrition Research Reviews 12 75-116.

Anthony RV, Pratt SL, Liang R \& Holland MD 1995 Placental-fetal hormonal interactions: impact on fetal growth. Journal of Animal Science 73 1861-1871.

Brandenberger AW, Tee MK, Lee JY, Chao V \& Jaffe RB 1997 Tissue distribution of estrogen receptors alpha (ER-alpha) and beta (ER-beta) mRNA in the midgestational human fetus. Journal of Clinical Endocrinology and Metabolism 82 3509-3512.

Breier BH, Gluckman PD \& Bass JJ 1988 Influence of nutritional status and oestradiol-17 beta on plasma growth hormone, insulin-like growth factors-I and -II and the response to exogenous growth hormone in young steers. Journal of Endocrinology 118 243-250.

Casanova M, You L, Gaido KW, Archibeque-Engle S, Janszen DB \& Heck HA 1999 Developmental effects of dietary phytoestrogens in Sprague-Dawley rats and interactions of genistein and daidzein with rat estrogen receptors alpha and beta in vitro. Toxicology Science $\mathbf{5 1}$ 236-244.

Clarke RB, Howell A \& Anderson E 1997 Type 1 insulin-like growth factor receptor gene expression in normal human breast tissue treated with oestrogen and progesterone. British Journal of Cancer 75 251-257.

Couse JF, Lindzey J, Grandien K, Gustafsson JA \& Korach KS 1997 Tissue distribution and quantitative analysis of estrogen receptoralpha (ERalpha) and estrogen receptor-beta (ERbeta) messenger ribonucleic acid in the wild-type and ERalpha-knockout mouse. Endocrinology 138 4613-4621.

Coxam V, Davicco MJ, Durand D, Bauchart D, Opmeer F \& Barlet JP 1990 Steroid hormone may modulate hepatic somatomedin C production in newborn calves. Biology of the Neonate 58 16-23.

D'Ercole AJ, Ye P, Calikoglu AS \& Gutierrez-Ospina G 1996 The role of the insulin-like growth factors in the central nervous system. Molecular Neurobiology 13 227-255. 
Diel P, Schulz T, Smolnikar K, Strunck E, Vollmer G \& Michna H 2000 Ability of xeno- and phytoestrogens to modulate expression of estrogen-sensitive genes in rat uterus: estrogenicity profiles and uterotropic activity. Journal of Steroid Biochemistry and Molecular Biology 73 1-10.

Enmark E \& Gustafsson JA 1999 Oestrogen receptors - an overview. Journal of Internal Medicine 246 133-138.

Ewton DZ, Falen SL \& Florini JR 1987 The type II insulin-like growth factor (IGF) receptor has low affinity for IGF-I analogs: pleiotypic actions of IGFs on myoblasts are apparently mediated by the type I receptor. Endocrinology 120 115-123.

Florini JR, Ewton DZ \& Coolican SA 1996 Growth hormone and the insulin-like growth factor system in myogenesis. Endocrine Reviews 17 481-517.

Gluckman PD 1997 Endocrine and nutritional regulation of prenatal growth. Acta Paediatrica Supplement 423 153-157.

Gustafsson JA 1999 Estrogen receptor beta - a new dimension in estrogen mechanism of action. Journal of Endocrinology 163 379-383.

Huang Z, Fasco MJ \& Kaminsky LS 1996 Optimization of Dnase I removal of contaminating DNA from RNA for use in quantitative RNA-PCR. Biotechniques 20 1012-1020.

Hufstedler GD, Gillman PL, Carstens GE, Greene LW \& Turner ND 1996 Physiological and hormonal responses of lambs repeatedly implanted with zeranol and provided with two levels of feed intake. Journal of Animal Science 74 2376-2384.

Klotz DM, Hewitt SC, Korach KS \& Diaugustine RP 2000 Activation of a uterine insulin-like growth factor I signaling pathway by clinical and environmental estrogens: requirement of estrogen receptor-alpha. Endocrinology 141 3430-3439.

Kuiper GG, Enmark E, Pelto-Huikko M, Nilsson S \& Gustafsson JA 1996 Cloning of a novel receptor expressed in rat prostate and ovary. PNAS 93 5925-5930.

Kuiper GG, Carlsson B, Grandien K, Enmark E, Haggblad J, Nilsson S \& Gustafsson JA 1997 Comparison of the ligand binding specificity and transcript tissue distribution of estrogen receptors alpha and beta. Endocrinology 138 863-870.

Kuiper GG, Shughrue PJ, Merchenthaler I \& Gustafsson JA 1998a The estrogen receptor beta subtype: a novel mediator of estrogen action in neuroendocrine systems. Frontiers in Neuroendocrinology 19 253-286.

Kuiper GG, Lemmen JG, Carlsson B, Corton JC, Safe SH , van der Saag PT, van der Burg B \& Gustafsson JA 1998b Interaction of estrogenic chemicals and phytoestrogens with estrogen receptor beta. Endocrinology 139 4252-4263.

Lamming GE 1957 The use of hormones in meat production. Agriculture Progress 23 1-8.

Lee AV, Jackson JG, Gooch JL, Hilsenbeck SG, Coronado-Heinsohn E, Osborne CK \& Yee D 1999 Enhancement of insulin-like growth factor signaling in human breast cancer: estrogen regulation of insulin receptor substrate-1 expression in vitro and in vivo. Molecular Endocrinology 13 787-796.

Liu GT, Zheng YL, Chen WH, Chen J \& Han ZK 1999 Effect of daidzein fed to pregnant sows on milk production and the levels of hormones in colostrum. Journal of Nanjing Agricultural University 22 69-72.

Makela S, Savolainen H, Aavik E, Myllarniemi M, Strauss L, Taskinen E, Gustafsson JA \& Hayry P 1999 Differentiation between vasculoprotective and uterotrophic effects of ligands with different binding affinities to estrogen receptors alpha and beta. PNAS 96 7077-7082.

Mitchner NA, Garlick C \& Ben-Jonathan N 1998 Cellular distribution and gene regulation of estrogen receptors alpha and beta in the rat pituitary gland. Endocrinology 139 3976-3983.

Ogiwara T, Chik CL \& Ho AK 1997 Tyrosine kinase inhibitors enhance GHRH-stimulated cAMP accumulation and GH release in rat anterior pituitary cells. Journal of Endocrinology 152 193-199.

Pau CY, Pau KY \& Spies HG 1998 Putative estrogen receptor beta and alpha mRNA expression in male and female rhesus macaques. Molecular and Cellular Endocrinology 146 59-68.
Phelps CJ, Wiggins JP \& Wangsness PJ 1988 Effects of zeranol on in vitro growth hormone release by lamb and rat pituitary cells. Journal of Animal Science 66 2614-2625.

Pons S \& Torres-Aleman I 1993 Estradiol modulates insulin-like growth factor-I receptors and binding proteins in neurons from the hypothalamus. Journal of Neuroendocrinology 5 267-271.

Pons S, Rejas MT \& Torres-Aleman I 1991 Ontogeny of insulin-like growth factor-I, its receptor, and its binding proteins in the rat hypothalamus. Brain Research. Brain Research Reviews 62 169-175.

Santell RC, Chang YC, Nair MG \& Helferich WG 1997 Dietary genistein exerts estrogenic effects upon the uterus, mammary gland and the hypothalamic/pituitary axis in rats. Journal of Nutrition 127 263-269.

Saunders PT 1998 Oestrogen receptor beta (ER beta). Reviews of Reproduction 3 164-171.

Schreihofer DA, Stoler MH \& Shupnik MA 2000 Differential expression and regulation of estrogen receptors (ERs) in rat pituitary and cell lines: estrogen decreases ERalpha protein and estrogen responsiveness. Endocrinology $1412174-2184$.

Setchell KD \& Cassidy A 1999 Dietary isoflavones: biological effects and relevance to human health. Journal of Nutrition 129 758S-767S.

Setchell KD, Zimmer-Nechemias L, Cai J \& Heubi JE 1998 Isoflavone content of infant formulas and the metabolic fate of these phytoestrogens in early life. American Journal of Clinical Nutrition $\mathbf{6 8}$ 1453S-1461S.

Sharpe RM 1998 The roles of oestrogen in the male. Trends in Endocrinology and Metabolism 9 371-377.

Shupnik MA, Pitt LK, Soh AY, Anderson A, Lopes MB \& Laws ERJ 1998 Selective expression of estrogen receptor alpha and beta isoforms in human pituitary tumors. Journal of Clinical Endocrinology and Metabolism 83 3965-3972.

Tena-Sempere M, Navarro J, Pinilla L, Gonzalez LC, Huhtaniemi I \& Aguilar E 2000 Neonatal exposure to estrogen differentially alters estrogen receptor alpha and beta mRNA expression in rat testis during postnatal development. Journal of Endocrinology 165 345-357.

Thomas MG, Carroll JA, Raymond SR, Matteri RL \& Keisler DH 2000 Transcriptional regulation of pituitary synthesis and secretion of growth hormone in growing wethers and the influence of zeranol on these mechanisms. Domestic Animal Endocrinology 18 309-324.

Toran-Allerand CD, Singh M \& Setalo GJ 1999 Novel mechanisms of estrogen action in the brain: new players in an old story. Frontiers in Neuroendocrinology 20 97-121.

Vanderschueren D, van Herck E, Nijs J, Ederveen AG, De Coster R \& Bouillon R 1997 Aromatase inhibition impairs skeletal modeling and decreases bone mineral density in growing male rats. Endocrinology 138 2301-2307.

Vidal O, Lindberg MK, Hollberg K, Baylink DJ, Andersson G, Lubahn DB, Mohan S, Gustafsson JA \& Ohlsson C 2000 Estrogen receptor specificity in the regulation of skeletal growth and maturation in male mice. PNAS 97 5474-5479.

Wang GJ, Han ZK \& Chen WH 1995 Effects of daidzein on the skeletal muscle growth and some plasma hormones levels in rats. Zoological Research 16 23-29.

Wilson ME, Price RHJ \& Handa RJ 1998 Estrogen receptor-beta messenger ribonucleic acid expression in the pituitary gland. Endocrinology 139 5151-5156.

Yu KT \& Czech MP 1984 The type I insulin-like growth factor receptor mediates the rapid effects of multiplication-stimulating activity on membrane transport systems in rat soleus muscle. Journal of Biological Chemistry 259 3090-3095.

Received 25 January 2001

Accepted 1 March 2001 